Овај рад има за циљ тумачење руске књижевности од стране Исидоре Секулић. Као основно полазиште узели смо њен есеј „Руска књижевност и студенти”, експлицитне исказе из 1922. године и лирско-медитативну прозу „Сапутници”. Истраживање применом плурализма метода биће нужно. Постављеном проблему приступићемо из перспективе парадигме, односно, основног обрасца који се јавља у више примера. Закључићемо да је самоћа била главна одредба живота и дела ове списатељице и анализа ће ићи трагом те чињенице.

Кључне речи: И. Секулић, руска књижевност, експлицитно, имплицитно, самоћа.

Исидора Секулић представља круну књижевног узлета и еманципације наше књижевности, достизање посебног сензибилитета и експресије. Она је служила свом народу на најбољи могући начин културно и нимало ограничено. Служила је с тежњом да разуме друге, да буде у извесном сродству с другим народима и њиховим културама. Отворена према светској култури, Секулићева је највише писала о руској, енглеској, француској, немачкој култури, о скандинавским књижевностима, а потом, у мањој мери, о неким античким писцима, о италијанској и другим културама и књижевностима.

Године 1922. Исидора Секулић је дала неколико експлицитних исказа везаних за Русију, руску културу и књижевност:

1. Русија је највећа држава на свету.

2. Руска црква је најраскошнија на свету.

3. Руски балет је најбољи на свету.

4. Руска револуција надмашује дубином и силином све револуције на свету.

5. Руско богатство је најнетакнутије на свету.

6. Руска књижевност је по идејама, прва у свету.

7. Русија која као држава, као војска, трговина, наука и религија, још није рекла своју громку и одлучну реч, али је Русија, као уметност рекла своју громку реч одавно.

1 snezanabascarevic@hotmail.com

2 Рад је урађен у оквиру пројекта Майеријална и духовна кулитура Косова и Мейохије, бр. 178028, који финансира Министарство просвете, науке и технолошког развоја Републике Србије. 
Наведене исказе користићемо као магистралне одерднице у трагању за одговором на питање: како је Исидора поимала руску књижевност и културу и колико су њени експлицитно-теоријски ставови имали имплицитну оствареност у ауторском тексту, узевши у обзир да је самоћа била одличје њеног система филозофије живота и филозофије уметности?

Први већи Исидорин рад о руској књижевности био је - „Руска књижевност и студенти” (1910). У то време она почиње да пише своје поетско-есејистичке записе „Сапутници” и овај рад ће ићи трагом те паралеле. Исидора је идеализовала руску литературу, посебно ону која стреми мистицизму:

„Цео свет је буржоазија, само Руси нису буржоазија! Ето у томе лежи све. И зато што су буржоазија ушли су у душу света и стоје изнад живота и људи, и чисти су и свети и кад се повлаче кроз блато живота, и кад гледају Богу и небу у очи. И зато што нису буржоазија ишчупали су сујету и лаж из човека, и унели у њ сумњу и апстракцију која иде до пропасти" (Sekulić 1977: 13).

Уочавамо да је овај текст похвала руском идеалистичком духу и руској књижевности, духовним трагањима за новим питањима и новим истинама. На његовом крају напомиње да је руска књижевност силна и дубока, да је она опасна за осетљиве и просечне људе. У трагању за везом између експлицитних и имплицитних одредница, уочавамо да је и сама Исидора била осетљив човек који је живео просечним животом. Читала је руску литературу и дивила се писцима попут Достојевског, о коме је написала два есеја: „Достојевски” и „О Достојевском”. У њима је истакла да дело Достојевског није уметност него сума, да он није одређен и одсечен него је остао громада; да се не може, због тога, упоређивати с другима, јер је сам у свему своме, чудесан, стихијски, без свршетка. Запажамо да су списатељске и карактерне особине Достојевског сличне Исидориним. Већ ови текстови показују да је Секулићева волела руску књижевност плодних мистичних и поетских мисли, морал, европску хришћанску књижевност и хуманистичку филозофију. У царство руске књижевности ушла је кроз врата руске приче о мраву, тигру и човеку, коју је као наравоученије навела на почетку есеја „Руска књижевност и студенти”.

О Исидори Секулић је створен мит који се више односи на њену личност него на стваралаштво. Књижевни савременици истицали су скромност, усамљеност, самоодрицање и неуморан рад ове списатељице. Окарактерисана је као особа у чијем је говору, понашању, одевању и животу било нечег монашког. Секулићева се више интуитивно одређивала према религији него што је о њој филозофски мислила. Писала је о вери, частољубљу, сиромаштву, правди, светости и самоћи. У есејима је тему о литерарном самовању проширила на човекову проблематику самотништва и судбинску контрадикторност, јер човек час тежи слави, час бежи у самоћу и анонимност. За руску меланхолију је експлицитно рекла да је најпоетичнија, а за руску осаму да је најстрашнија на свету. И сама није могла да избегне тај контраст. Самоћа се јавља као главна 
одредба људског трајања, без обзира да ли је споља наметнута или је човек сам изграђује и остварује. У запису „Буре” налазимо имплицитну одредницу на исту тему: „Седела сам, дакле, по цео дан сама, у каквом кутићу, и превртала шарене и светле картоне по лексиконима и књигама природних наука" (Sekulić 1994: 7). То су сећања на доживљаје из детињства и девојачку усамљеност; док се у запису „Самоћа” пита:

„Зашто у овој самоћи не видим онај светли сребрни блесак сунчева рођења који сећа на маслинове шуме левантских острва. Зашто су ме оставиле оне велике екстазе кад сам нетремице гледала сунцу у чело и са засенутим очима газила преко сенки које нисам опажала" (Sekulić 1994: 33).

У овом цитату писац, лирик, добија подршку есејисте, и долази до споја лирског и есејистичког казивања. Мало ко је у нашој књижевности говорио тако душевно и мисаоно узнемирено о самоћи као што је то учинила Исидора Секулић.

Кроз прозу „Сапутници”, сагледавајући човека у оквиру његовог религијског и културног бића, Исидора дијагностицира његове проблеме и тражи најадекватнији пут за излаз из замршеног душевног лавиринта. Строга према себи и критички праведна према другима, својим делом и понашањем постала је узор часне и храбре интелектуалке. На једном месту у есеју „Руска књижевност и студенти” истакла је да су Руси уништили мир и срећу човечју и на престо среће попели генија бола и трпљења. Секулићева је живела по сличном моделу. Пишући о другима, бавећи се другима, приближавала се себи и у процесу индивидуације и обожења упознавала себе. Она је могла да досегне духовне висине, јер је имала смелости да се спусти до најдубљих слојева човековог бића, да укаже на сложене аспекте његове религозности. Праћено вером и прожето љубављу, силажење до несвесних темеља био је пут ка божанским висинама. У тој двосмерности која претпоставља највеће дубине и највеће висине, садржане су могућности човека да буде оно што може бити, али често и мањи и већи од себе.

Нагласили смо да је ова списатељица стварала снагом која је поникла у самоћи. Све текстове књиге „Сапутници” вежу теме самоће и туге, од приче „Буре”, у којој самотно дете исказује своје жеље, па до записа „Круг”, где ауторско лице показује страх од самоће. Теме туге и самоће провлаче се и записом „Литургија”. После тужних осећања везаних за природу („Има нешто сетно и снуждено у слагању жутих и плавих боја” - Sekulić 1994: 73), после сетних контемплација, читамо ове мисли: „Тако сам сама и сиромашна. Путници и просјаци и лађе и таласи и време, све пролази поред мене без везе са мном, без поздрава и без пријатељства према мени" (Секулић 1994: 77). У есеју који је у фокусу наше анализе пише: „Ала је тужна та Русија” (Sekulić 1977: 189).

Још један реалан узрок из реда оних који су условили код Исидоре Секулић јако осећање усамљености и рано је упутили на свет уметности у којем је налазила утеху, био је лишеност благотворног утицаја што долази од блиских другарстава и прихватања савременика. 
У детињству је почела њена осуђеност на самоћу. Нада Маринковић је у књизи студија и огледа Јасна йољана записала исповест Исидоре Секулић да је патила због тога што је била друкчија од својих вршњака па су се клонили од ње: „Родила сам се начета, најпре нерви, затим плућа, шкофуле [...] неко се роди и расте упијајући у себе љубав за благостање и ведрину, ја сам расла под дахом смрти" (Marinković 1963: 218).

На исту тему у есеју „Руска књижевност и суденти” пише: „Руски писци комад по комад цепају људске проблеме, и у сваком комадићу износе откуцаје живота и болести духа и тела" (Sekulić 1977: 182). Затим је у једном од есеја забележила изјаву Достојевског: „Ја сам болестан човек”. Исидора је у ауторском тексту о себи писала готово исто.

У „Сапутницима” на тему самотништва наставља: „Било је неке коби у моме детињству, протеклом мимо људи ко што ће ми протећи, касније, и читав живот, али сам имала ретку срећу да од првих корака будем бачена у свет науке и рада, што ће рећи да сам зарана упућена на саму себе. Због таквог друкчијег мог живота деца ме нису схватила и ја нисам налазила додирне тачке са њима. Врло рано почела је моја осуђеност" (Sekulić 1994: 220).

Још једном ради остваривања паралеле наводимо пример из поменутог есеја:

„Етичка жица целе руске литературе јесте страсно тражење чистог и непоквареног човечанства. Руси слепо верују да то непокварено човечанство, ма колико било укаљано, постоји, и да се ничим не да избрисати. [...] Човека треба волети због оног доброг и лепог што је у њему, а што он не зна да има, у томе лежи утешна етика руске књижевности" (Sekulić 1977: 188).

Горка искуства су је гонила у осуђеност на самоћу, као нужни избор, и пробудила иначе необично изражене способности схватања свега људског, а нарочито људских патњи. Лична искуства су проузроковала да се Исидора Секулић страсно залагала у својим есејима за тумачење судбина неприхваћених људи. Проблем је шире, теоријски разматрала, и чешће је опомињала да неразумевање и прећуткивање убијају. Писала је да су руски писци претерали у својим теоријама о чистоти.

О неприхватањима, међусобним издвојеностима, осећању усамљености и узнемирености писала је да то није само њен проблем. Видела је да усамљивања постају све шира појава и схватила друштвене узроке те појаве. Вера је била извор њеног смирења и позитивних доживљаја.

Исидора је разликовала две врсте усамљеника. Оне који су јаки, и самују по својој непоколебљивој вољи, и друге, који су усамљеници по судбини и нужди. Себе и писце најмлађе генерације око рата и после рата убрајала је у другу врсту. „Њихово самовање није увек, као оно малочас споменуто, самовање снаге, него понајчешће самовање осетљивости, очајања, скепсе, страха. Али како самоћа, ма како да почне, увек чисти, челичи и диже, тако и те самоће постају све занимљивије и боље” (Sekulić 1964: 238). Подвучена мисао да и самоћа може уздићи човека, сагласна је са њеним уверењем да је зло подстицај за добро и да је пред чо- 
веком безброј могућности за премошћавање супротности, али да их он мора откривати и освајати. То је сагласно са изјавом Исидоре Секулић да се човек, као и дијамант, само својим прахом чисти и полира. За њу је човек ставаралац и борац који изналази могућности за савлађивање својих и општих контраста и невоља. Она је за себе ту могућност видела, поред свесно неговане вере, највише у раду. У есеју „Руска књиженост и студенти” пише: „Али бити човек, који је већ зачетком својим резултат компромиса, и не хтети компромис; и живети међу људима, а не хтети бити буржоазија, то су елементи трагичног сукоба" (Sekulić 1977: 182).

На крају закључујемо да је Исидора Секулић стварала снагом која је поникла у стваралачкој самоћи по узору на руске писце. Руска уметност је за њу у основи религиозна и трагична, и ту је видела највиши израз духовности. Веровала је да је услов сваке велике уметности духовна аскеза и истицала да Руси пропагирају филозофску скрушеност, али не као филозофију немоћи него као филозофију надмоћи. Уочила је да руска књижевност огромно и неописиво утиче на младе читаоце када у њој први пут нађу уважење истинског живота. Њени експлицитно-теоријски ставови на тему руске културе и књижевности имали су делимичну имплицитну оствареност у ауторском тексту лирско-медитативне прозе „Сапутници" и тако одредили карактер њене прозе.

\section{Листа референци}

Deretić, 1997: J. Deretić, Poetika srpske književnosti, Beograd: Filip Višnjić. [orig.] Деретић, 1997: J.

Деретић, Поеиика срйске књижевносиии, Београд: Филип Вишњић.

Dučić 1914: J. Dučić, Isidora Sekulić, Srpski književni glasnik, (16. aprila), br.8, XXXII, Beograd, 583-586. [orig.] Дучић 1914: J. Дучић, Исидора Секулић, Срйски книжевни гласник, (16. априла), бр.8, XXXII, Београд, 583-586.

Egerić 1982: M. Egerić, Ime i delo Isidore Sekulić, Beograd: Rad. [orig.] Егерић 1982: М. Егерић, Име и gело Исияоре Секулић, Београд: Рад.

Ejhenbaum 1972: B. Ejhenbaum, Književnost, Beograd: Nolit. [orig.] Ејхенбаум 1972: Б. Ејхенбаум, Кюижевносии, Београд: Нолит.

Epštajn 1997: M. Epštajn, Esej, Beograd: Narodna knjiga/Alfa. [orig.] Епштајн 1997: М. Епштајн, Есеј, Београд: Народна књига/Алфа.

Hristić 1968: J. Hristić, Oblici moderne književnosti, Beograd. [orig.] Христић 1968: J. Христић, Облищи модерне кюижевносиии, Београд.

Ignjatović 1992: M. D. Ignjatović, Književna kritika i savremene teorije tumačenja književnog dela, Beograd: Stručna knjiga. [orig.] Игњатовић 1992: М. Д.

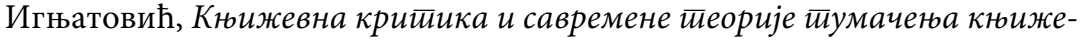
вног gела, Београд: Стручна књига.

Leovac 1986: S. Leovac, Književno delo Isidore Sekulić, Beograd: Vuk Karadžić. [orig.] Леовац 1986: С. Леовац, Кюижевно gело Исияоре Секулић, Београд: Вук Караџић.

Marinković 1963: N. Marinković, Jasna poljana, Beograd: Kosmos. [orig.] Маринковић 1963: Н. Маринковић, Јасна иольана, Београд: Космос. 
Matoš 1952: A. G. Matoš, Eseji i feljtoni o srpskim piscima, Beograd. [orig.] Матош 1952: А. Г. Матош, Есеји и фельйони о срйским ииисцима, Београд.

Novaković 1959: B. Novaković, Lik i delo Isidore Sekulić, Beograd: Nolit. [orig.] Новаковић 1959: Б. Новаковић, Лик и gело Исияоре Секулић, Београд: Нолит.

Pejić 1973: S. Pejić, Patografija književnice Isidore Sekulić, Novi Sad: Sekcija SAP Vojvodine. [orig.]

Пејић 1973: С. Пејић, Пайогррафија књижевнице Исияоре Секулић, Нови Сад: Секција САП Војводине.

Popović 1984: R. Popović, Moj krug kredom, Beograd: Narodna knjiga. [orig.] Поповић 1984: Р.

Поповић, Мој круг̄ креgом, Београд: Народна књига.

Sekulić 1964: I. Sekulić, Iz stranih književnosti I, Subotica: Matica srpska. [orig.] Ce-

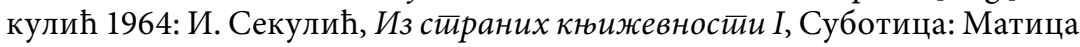
српска.

Sekulić 1964: I. Sekulić, Zapisi, Subotica: Matica srpska. [orig.] Секулић 1964: И. Секулић, Заииси, Суботица: Матица српска.

Sekulić 1964: I. Sekulić, Teme, Subotica: Matica srpska. [orig.] Секулић 1964: И. Секулић, Теме, Суботица: Матица српска.

Sekulić 1964: I. Sekulić, Analitički trenuci, Subotica: Matica srpska. [orig.] Секулић 1964: И. Секулић, Аналитички ирренуци, Суботица: Матица српска.

Sekulić 1977: I. Sekulić, Iz stranih književnosti II, Beograd: Vuk Karadžić. [orig.] Секулић 1977: И. Секулић, Из сшираних књижевности II, Београд: Вук Караџић.

Sekulić 1994: I. Sekulić, Saputnici, Beograd: Plavi jahač. [orig.] Секулић 1994: И. Секулић, Сайуйници, Београд: Плави јахач.

Skerlić 1913: J. Skerlić, Dve ženske knjige, Srpski književni glasnik, (1. septembra), br. 303, (XXXI, sv. 5), Beograd, 386. [orig.] Скерлић 1913: J. Скерлић, Две женске књиге, Срйски

књижевни глласник, (1. септембра), бр. 303, (XXXI, св. 5), Београд, 386.

Starobinski 2011: Ž. Starobinski, Melanholija u ogledalu, Loznica: Karpos. [orig.] Старобински 2011: Ж. Старобински, Меланхолија у оглеgалу, Лозница: Карпос.

Vatomo 1991: Đ. Vatomo, Kraj moderne, Novi Sad. [orig.] Ватомо 1991: Ђ. Ватомо, Крај моgерне, Нови Сад.

Vuksanović 1999: O. Vuksanović, Smisao samoće u delu Isidore Sekulić, Niš: Filozofski fakultet. [orig.] Вуксановић 1999: О. Вуксановић, Смисао самоће у gелу Исияоре Секулић, Ниш: Филозофски факултет.

Žmegač 1986: V. Žmegač, Težišta modernizma, Zagreb. [orig.] Жмегач 1986: В. Жмегач, Тежишйа моgернизма, Загреб. 


\section{Snežana S. Baščarević ISIDORA SEKULIĆ’S EXPLICIT AND IMPLICIT STANCES ON RUSSIAN LITERATURE}

Summary

The paper explores Isidora Sekulić's understanding of Russian literature based on her essay "Russian Literature and Students", explicit statements from 1922 and her lyrically meditative prose piece "Fellow Travellers". Solitude was the chief factor in life and work of this authoress and the analysis will follow the path of that fact. The conclusion is that Isidora Sekulić wrote with strength which originated from creative solitude, using Russian writers as a model. For her, Russian art was essentially religious and tragic, which she saw as the highest expression of spirituality. She believed that the condition for all great art was spiritual asceticism and pointed out that Russians propagated philosophical humbleness not as a philosophy of infirmity, but as a philosophy of mastery. She observed that Russian literature was an enormous influence on young readers, because what they found in it for the first time was respect for true life. Her explicit theoretical standpoints regarding Russian culture and literature had a partial implicit realization in "Fellow Travellers" and determined the character of her prose.

Key words: Isidora Sekulić, Russian literature, explicit, implicit, loneliness

Примъен 13. маја 2017. голине Прихваћен 14. сеитиембра 2017. голине 